石油技術協会誌 第 84 巻 第 1 号 （平成 31 年 1 月） $42 \sim 51$ 頁 Journal of the Japanese Association for Petroleum Technology

Vol. 84, No. 1 (Jan., 2019) pp. 42 51

\begin{tabular}{l}
\hline 講 演 \\
Lecture \\
\hline
\end{tabular}

\title{
多種物理探査デー夕統合解析・評価による構造形態推定と岩相推定*
}

\author{
高井 克己 ${ }^{* *,+} \cdot$ 東中 基倫 $^{* * *} \cdot$ 持永 尚子 ${ }^{* * *}$
}

(Received September 17, 2018 ; accepted November 6, 2018)

\section{Multi-physics data integration for interpretation and lithology classification}

Katsumi Takai, Motonori Higashinaka and Hisako Mochinaga

\begin{abstract}
In recent years, the progress of data acquisition and analysis technology is remarkable in the field of non-seismic. Comprehensive evaluation of seismic data and non-seismic data is becoming important to increase success probability in exploration field. However, there are many issues to be considered for effective utilization, such as sensitivity and resolution of each data. In this paper, we introduce current status and problems of attempts to estimate structure and lithofacies by integrated analysis using multi-species geophysical data.
\end{abstract}

Keywords : non-seismic, multi-physics, lithology classification

1.はじめに

近年, 空中重力・磁気探査および海洋電磁探査に関して, 高解像度の実現とともに, 物性・岩相情報抽出に向けたデー 夕取得および解析技術の進展が顕著である。低油価が継続 する現状において, 石油・天然ガス資源探鉱における地質 的成功確率評価の精度向上, 迅速な探鉱開発は喫緊の課題 であり, 地震探查デー夕に Non-Seismic デー夕を加えた統 合解析・評価への期待・ニーズは非常に高い。実際に, 海 洋電磁探査デー夕を用いた HCI (Hydrocarbon Indicator) 再評価を通じた探鉱成功事例がバレンツ海などで報告され ている (Stein et al., 2014)。また, 東アフリカ地域などの 難地域では, 空中重力偏差および MT を含む Non-Seismic データをプロスペクト抽出に積極的に活用する事例が報告 されている (Colombo et al., 2012)。さらに, 重力偏差法 探査に続き磁力偏差法探査も開発され, 重力探査, 電磁探 査より探鉱開発への貢献が少なかった磁力探査に関して も，有意な成果を提示できる可能性が見いだされている。 一方で, 複数の Non-Seismic データを用いた複合解析,

\footnotetext{
* 平成 30 年 6 月 13 日, 平成 30 年度石油技術協会春季講演会 地質 探鉱部門シンポジウム「効率化と技術の進展が石油・天然ガス探鉱 にもたらす影響」で講演 This paper was presented at the 2018 JAPT Geology and Exploration Symposium entitled "Impacts of Efficiency and Technology Development on Oil and Gas Exploration” held in Niigata, Japan, June 13, 2018

** 石油資源開発株式会社 JAPEX

*** (株)地球科学総合研究所 JGI, Inc

† Corresponding author : E-Mail : katsumi.takai@japex.co.jp
}

統合インバージョンおよびモデリングを通じて，構造把握 に止まらず，物性情報からマクロな岩相モデル構築が期待 されているが, 個別の物性不均質構造を踏まえた有効活用 には, 各インバージョン解析の感度, 分解能などの相違点 の把握が必要であり考慮すべき課題は多い。

本稿では, 多種物理探査デー夕を用いて統合解析・評価 による構造形態推定と岩相推定の試みの現状と課題につい て実証スタディを通じて紹介する。

\section{Non-Seismic データの重要性と技術進展}

石油業界において, 高分解能である地震探査デー夕の使 用頻度は高く, 重・磁力探査デー夕は, 地震探査データの 断面図上部に異常值を投影し構造区分の把握に活用する場 合や，平面図でコンター間隔の粗密や異常值のトレンド変 化からリニアメント解析を行い断層位置の推定に活用する

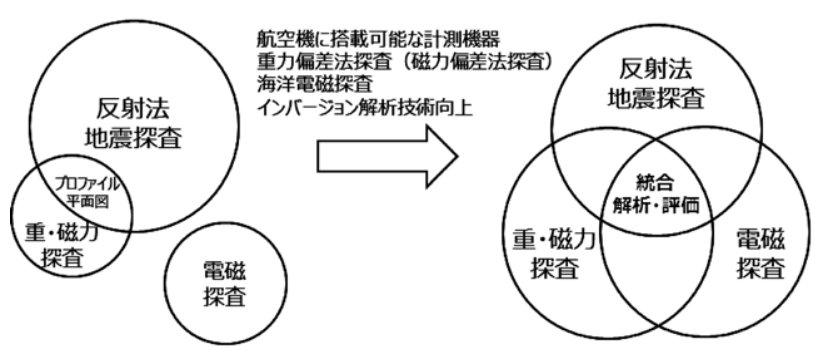

図 1 各種物理探査データの統合評価に関わる概念図 既往概念から測定・解析技術が向上した将来の概念を示す。 
など補助的に活用されてきた。

また, 電磁探査デー夕の使用頻度は低く, 地熱開発など の他分野で主に使用されるに留まっていた。しかしながら, 重力偏差法探査や磁力偏差法探査の開発, 海洋電磁探査の 実用化やインバージョン解析技術の向上によって，地震探 查に比べて低分解能ではあるが異なる物性值について高精 度に測定することが可能となり，石油・天然ガス資源探鉱 における地質的成功確率評価の精度向上，迅速な探鉱開発 実施に応えるため, 地震探査データに Non-Seismic データ を加えた総合解析・評価への期待が高まってきている。図 1 に各物理探査デー夕統合評価に関する概念図を示す。

近年の測定技術進展においては，重力偏差法探査で使用 される測定機器がへリコプターに搭載可能となるほど小型 軽量化され, 陸上重力探査と同等以上の空間分解能となり, 地形が険しく陸路ではアクセス困難な地域においても高精 度の重力探査が可能となってきている（Mark Dransfield, 2010)。図 2 に衛星重力, 地上重力, 空中重力, 空中重力
偏差法による解析結果の比較図を示す。

また, 海洋電磁探査においては, 地震探査データから解 釈されたホライゾンを拘束条件として，ホライゾン以深の 比抵抗值を探索するインバージョン解析を行い, 高比抵抗 域を抽出し炭化水素の存在を示す指標として使用され，探 鉱開発に貢献できるようになってきている（S.Chakraborty et al., 2013)。図 3 の地震探査断面からは Well-1 と Well-2 の構造に違いは認められない。しかし, 海洋電磁探査のイ ンバージョン結果を重ね合わせと Well-1の構造と高比抵 抗域が一致しており，ガス飽和率の高い貯留層と解釈され ている。

\section{3. 多種物理探査デー夕統合解析・評価 の技術開発に関わる実証スタディ}

本実証スタディの目的は, 多種物理探査デー夕を用いた 統合解析・評価を通じて, スタディ地域の主要層の構造形 態推定と主要岩相の分布推定について，その解析手法の標

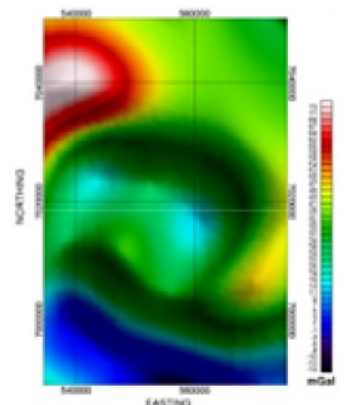

衛星重力 (DNSC08)

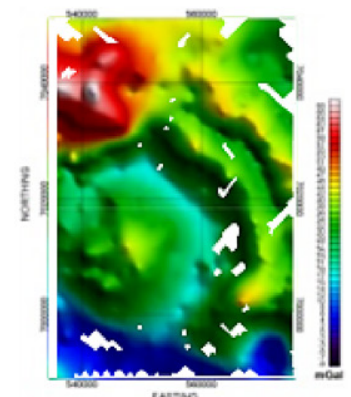

地上重力

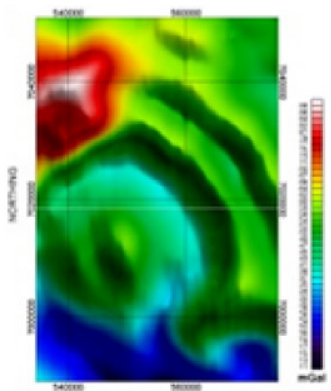

空中重力

(GT-1A)

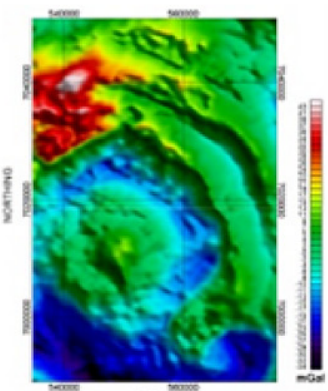

空中重力偏差

(FALCON AGG)

(Mark Dransdield, 2010)

図 2 各種重力探査の比較図

測定手法の違いによる分解能の違いを示す。陸上重力探査は短波長の変化が捉えられているが，アクセスできない空白域がある。し かし, 空中重力偏差法探査では, 空中から測定を行うことによってアクセスできない地域は存在しない。

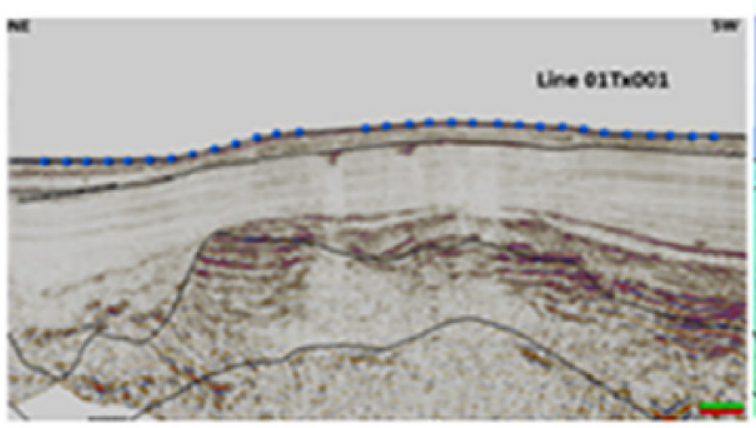

図 3 海洋電磁探査の使用例

左に地震探査断面，右に地震探査断面に比抵抗值を重ね合わせした図を示す。Well-1 構造が高比抵抗域となっており Well-2 構造とは 異なることが分かる。 
準化を試みるとともに，技術課題を精査することである。 その結果, 解析手法の標準化として, 後述の基本手順を作 成し他地域への適応の可能性が見いだされ，インバージョ

\section{重·磁力探査}

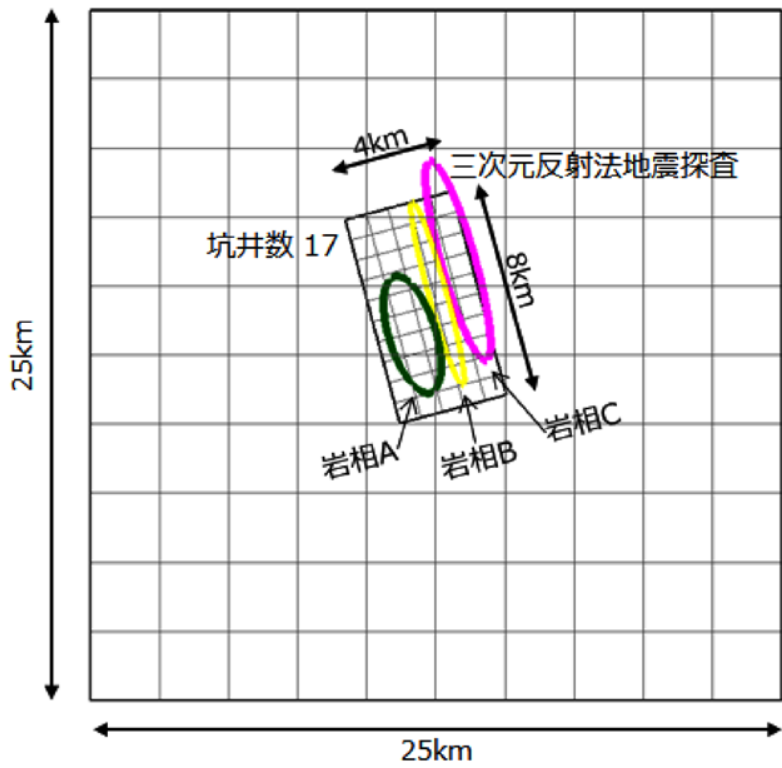

図 4 実証スタディ対象の物理探査データと岩相分布域 重・磁力探査データの三次元インバージョン実施範囲 $(25$ $\mathrm{km} \times 25 \mathrm{~km})$ と三次元地震探査デー夕範囲 $(4 \mathrm{~km} \times 8$ $\mathrm{km})$ ，坑井地質から推定された岩相 $\mathrm{A}, \mathrm{B}, \mathrm{C}$ の分布域を示す。
ン解析において技術課題が明らかになつた。

3.1 実証スタディ対象の概要

スタディ地域は, 主要層の第 1 層および第 3 層, 主要層 に挟まれた第 2 層の 3 層から構成されており，第 1 層およ び第 3 層の構造形態は, 三次元地震探査デー夕から解釈を 行うことによって推定はされている。本稿では，第 1,3 層 の既存解釈と解析手法の標準化で推定された構造形態との 整合性を評価する。一方, 主要岩相は, A, B, C の 3 岩 相から構成されており，火成岩相 A， B，Cの分布につい ては，西から東へ A， B，Cと大よその分布域が坑井地質 から推定されている（図 4)。

スタディ地域の物理探査デー夕は, 三次元地震探査 $(4$ $\mathrm{km} \times 8 \mathrm{~km})$ が約 $32 \mathrm{~km}^{2}$ ，陸上重力探査 $(25 \mathrm{~km} \times 25$ $\mathrm{km})$ が約 500 点, 地質調査総合センター（2005）の空中 磁気異常データベース $(25 \mathrm{~km} \times 25 \mathrm{~km})$ が使用可能であ る（図 4)。また, 地域内には 17 坑井があり, 検層デー夕 および FMI を解析することによって岩相区分がなされて いる。

3.2 統合解析・評価の基本手順

実証デー夕の事例適用に際して, 三次元物性モデルの構 築，疑似検層デー夕の作成を経て，構造形態および岩相推 定を実施した。以下に基本手順を示し，解析手法の標準化 とした。

[1] 入手可能な物理探査データと地表地質状況および坑井 情報などの知見を統合して, 大まかな構造形態と岩相 分布域を推定し，品質管理のための資料を作成する。

[2] 物理探査デー夕について解析又は処理を行い, デー夕 に含まれる物性值を取り出し，1つのセルに速度，密

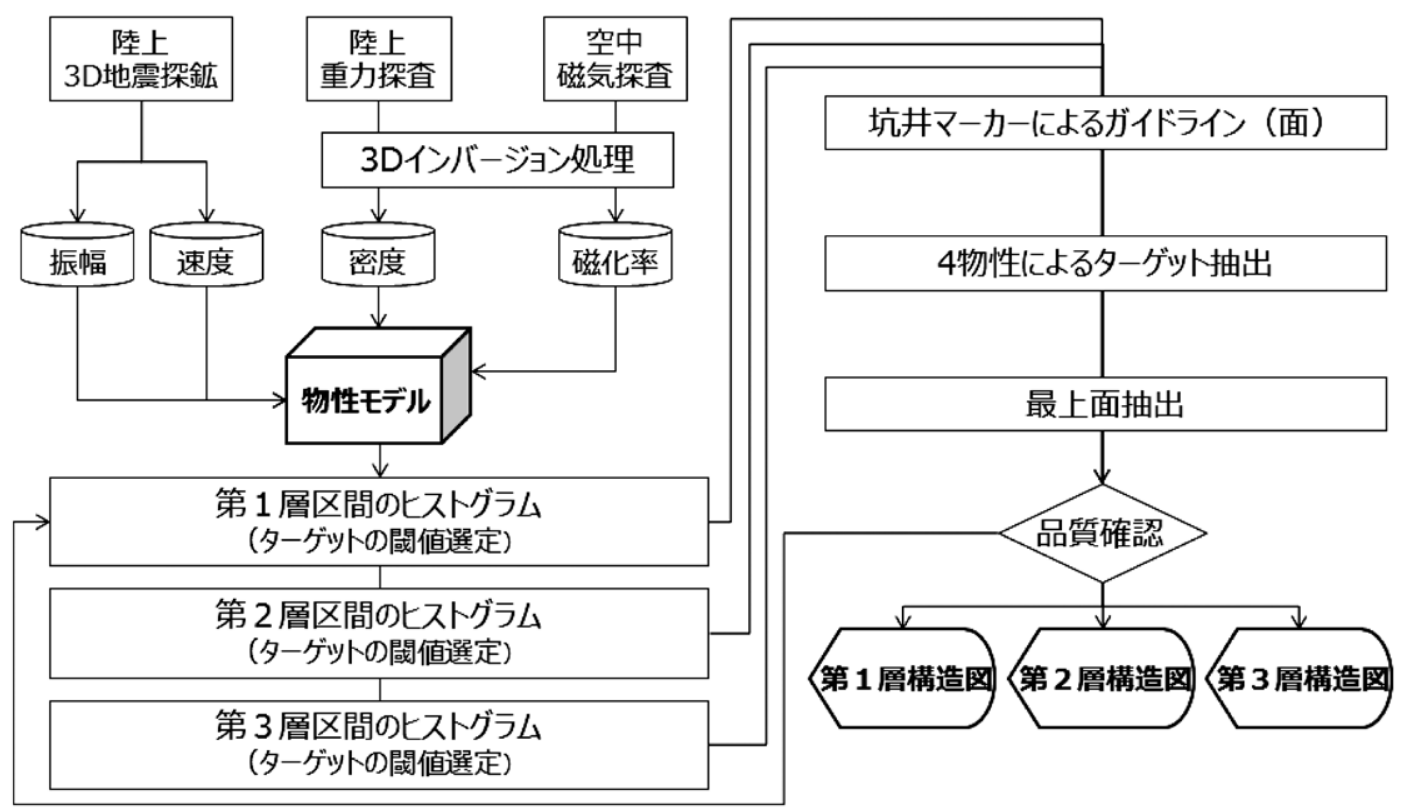

図 5 構造形態推定ワークフロー図

4 物性值を保持した物性モデルからしきい值内のセルを抽出し，各層準の構造図を作成するフローを示す。 


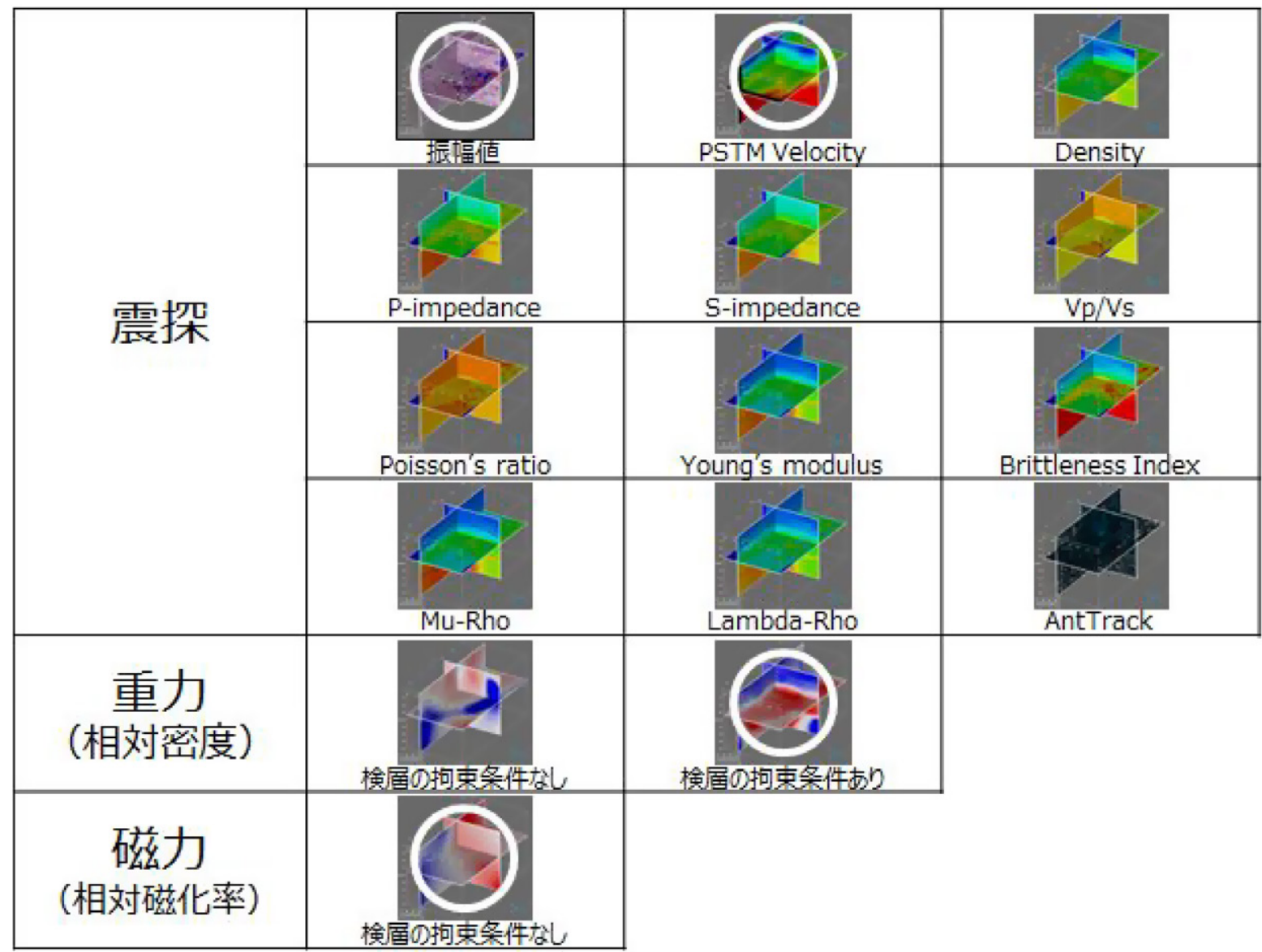

図 6 構造形態推定で使用したデー夕

マルチアトリビュート解析によって各種物性が取り出されているが, 構造形態推定では 4 物性（白丸）を使用した。

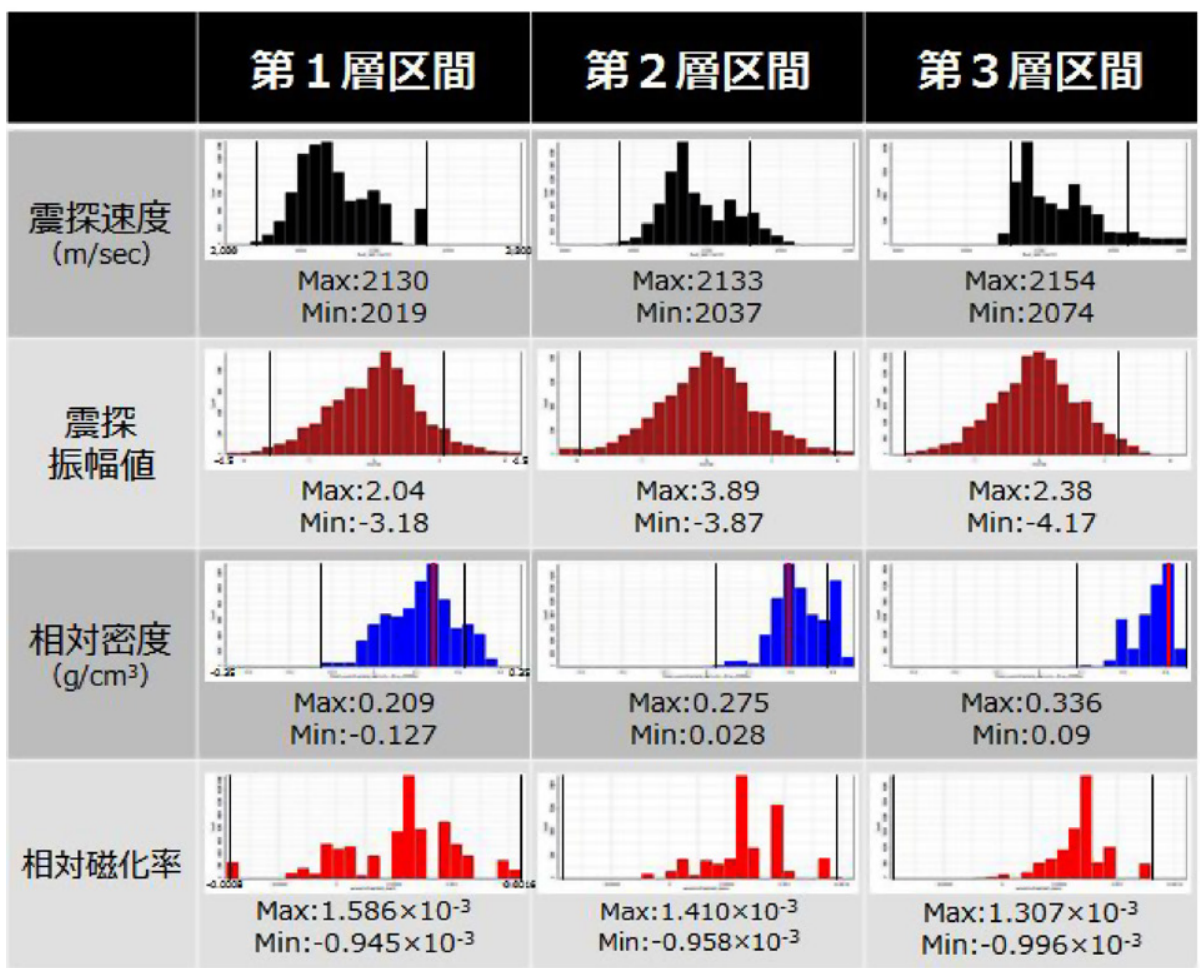

図 7 構造形態推定で使用したデータのヒストグラムと最適なしきい值 選定した 4 物性における層準区間ごとのヒストグラムと最適なしきい值（Max，Min）を示す。 
度, 磁化率などの複数の物性值が保管されている三次 元物性モデルを構築する。

［3］構築された三次元物性モデルから, 坑跡に沿って各物 性值を取り出し疑似検層デー夕を作成する。

[4] 坑井情報には夕ーゲットとする層準または岩相の区間 が認定されており, 認定区間内における疑似検層デー タからヒストグラムを作成する。

［5］ヒストグラムから使用する物性值と最適なしきい值を 選定する。

[6] 三次元物性モデルから全物性值のしきい值に収まるセ ルを抽出し，構造図または岩相分布域を作図する。

［7］１］で作成した品質管理資料の大まかな構造形態と岩 相分布域と比較し, 地質学的観点とのそごが生じた場 合には，しきい值を見直し再度抽出を行う。

[8］地質学的観点とのそごがなくなつたと判断した場合, 終了とする。

さらに, しきい值が重なり岩相が複数抽出されることが
予想されるため, 抽出されたセルにはフラグを立て, 各セ ルにおける出現率を算出し保管しておく。出現率を算出す ることによって，複数の岩相に対しても抽出が可能となる が，1つのセルが単一岩相として認定されていない場合が あることに留意が必要である。

\section{3 構造形態推定結果}

構造形態推定手順については, 三次元物性モデルから坑 跡に沿つて各物性值を取り出し疑似検層デー夕を作成し, ターゲットとする層準区間内の物性值のヒストグラムを作 成する。ヒストグラムから使用する物性值と最適なしきい 值を選定後, 三次元物性モデルから全物性值のしきい值に 収まるセルを抽出し構造図を作図した。構造形態推定を 行ったワークフローを図 5 に示す。

使用したデータは, 三次元地震探査処理結果の振幅值と 速度解析結果の速度值, 陸上重力探査データに対して検層 データを拘束条件として加えた三次元インバージョン解析 後の相対密度值（深部になるほど密度が高くなる傾向を除

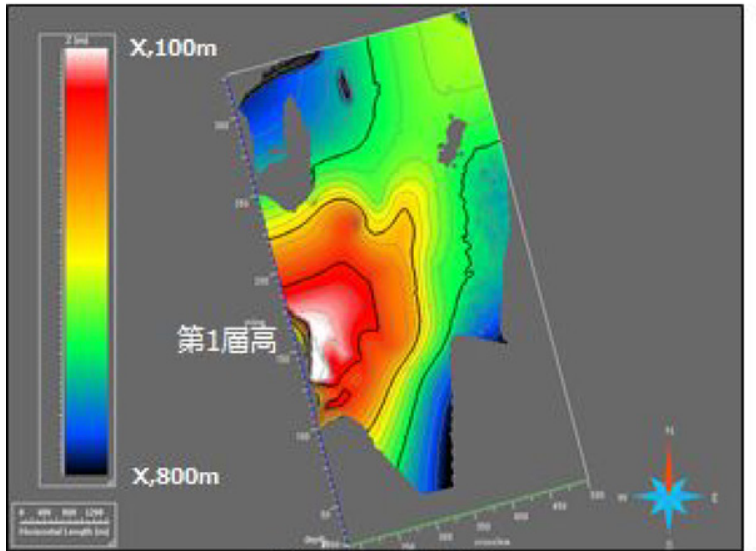

第 1 層上面

(図5ワークフローから作成)

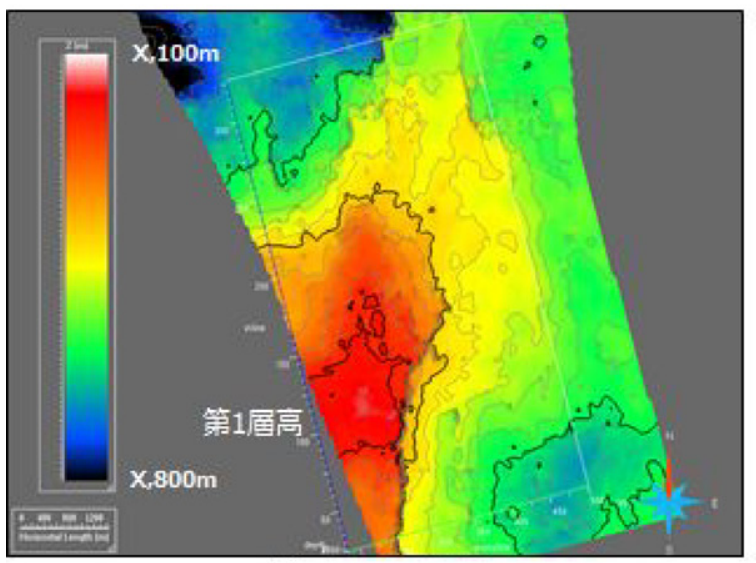

第 1 層上面 （既往震探解釈）

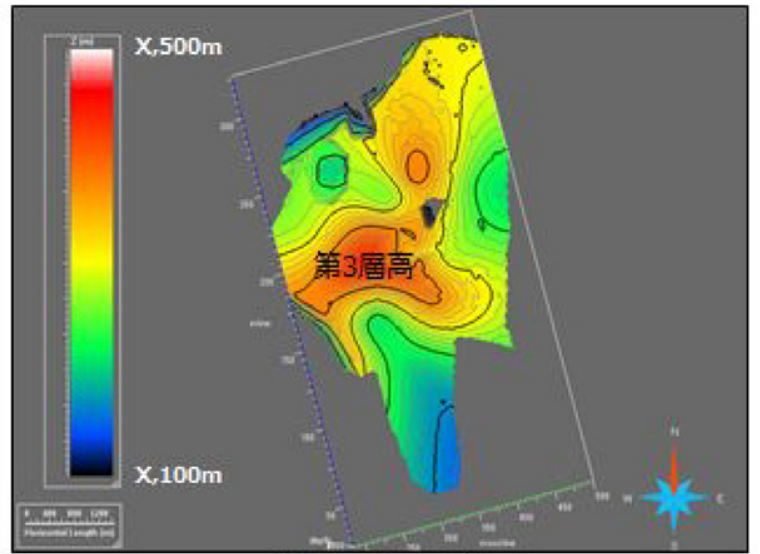

第 3 層上面

(図5ワークフローから作成)

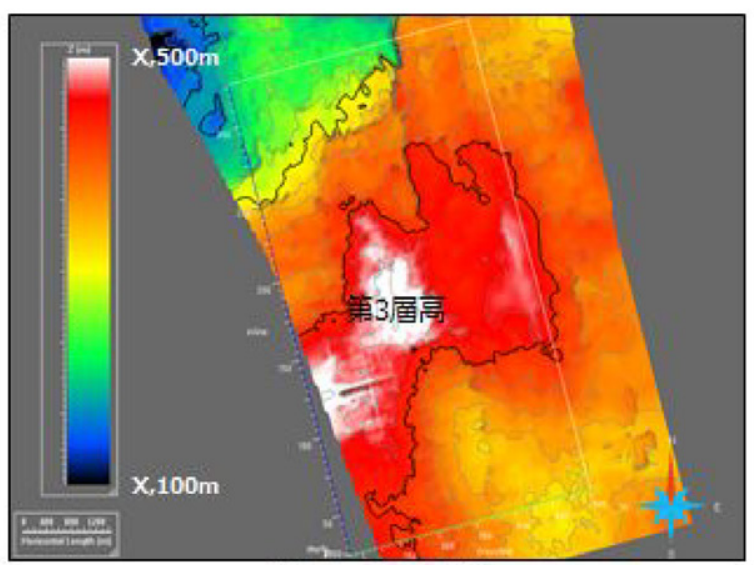

第 3 層上面 (既往震探解釈)

図 8 構造形態推定結果と既存構造図

上段が図 5 のワークフローから作成された構造図, 下段が既往震探解釈結果から作成された構造図を示す。 


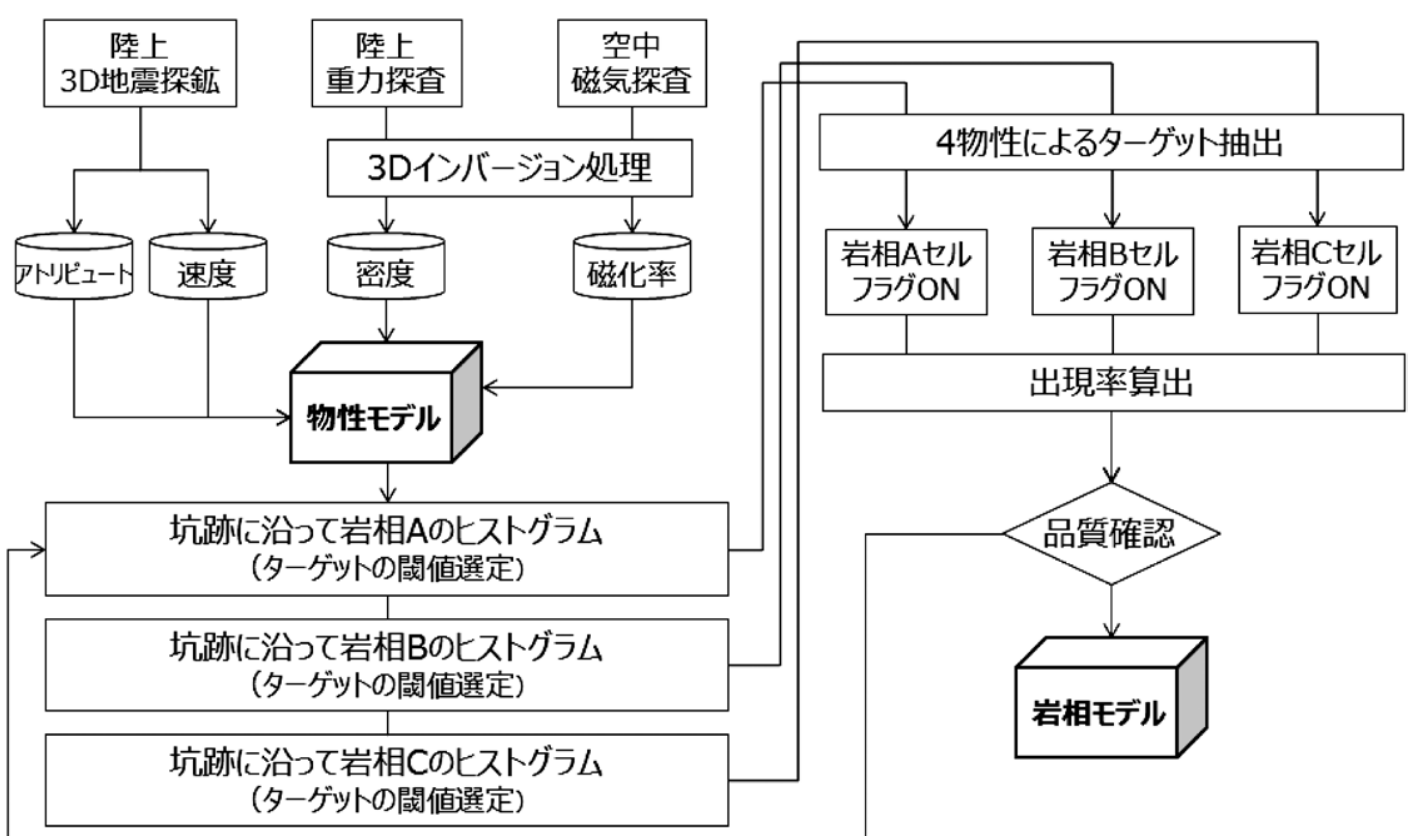

図 9 岩相推定ワークフロー図

4 物性値を保持した物性モデルからしきい值内のセルを抽出し，岩相モデルを構築するフローを示す。

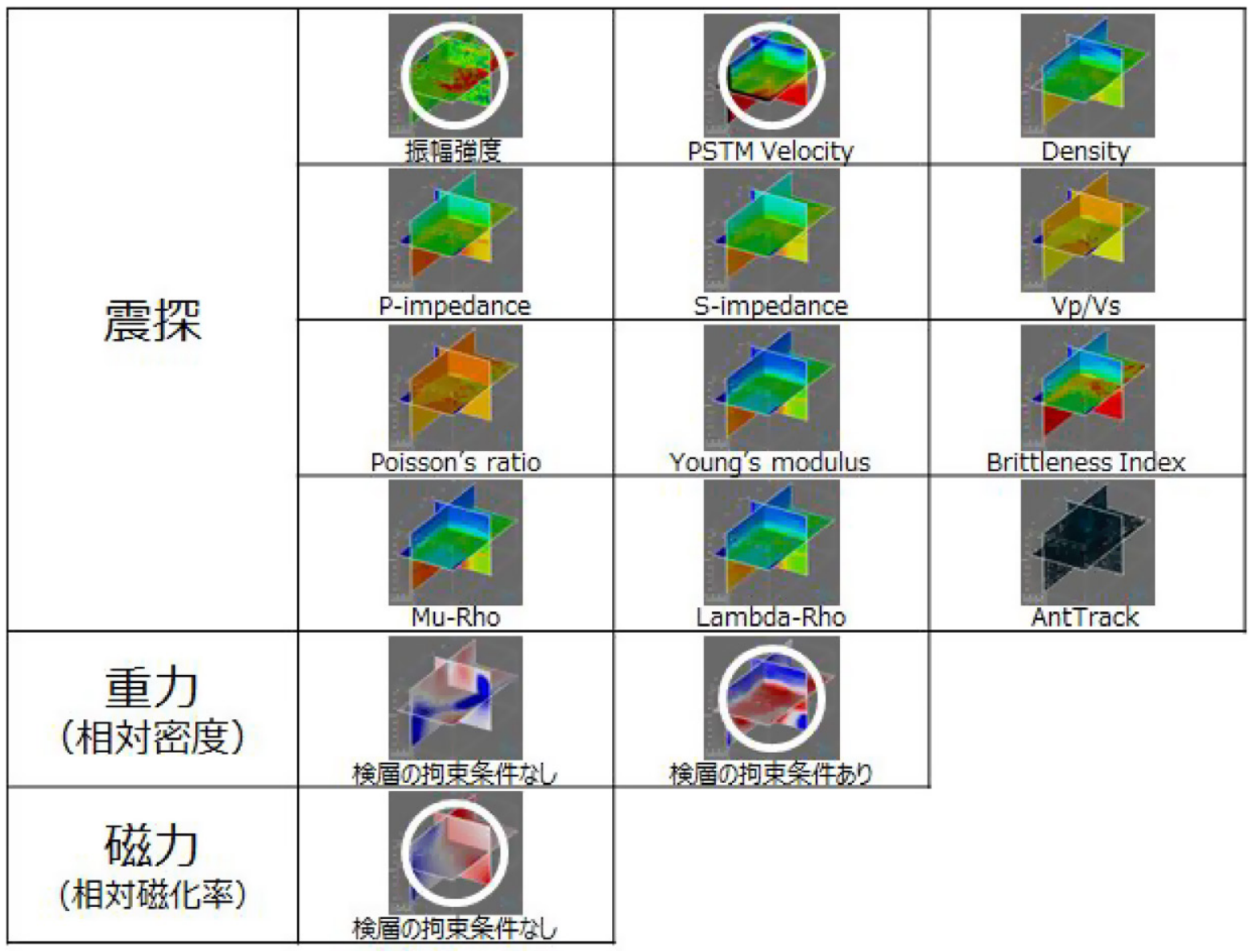

図 10 岩相推定で使用した 4 物性デー夕

岩相推定では 4 物性（白丸）を使用した。 
いた密度), 空中磁気探査を拘束条件なしで行った三次元 インバージョン解析後の相対磁化率值（傾向面を除いた磁 化率)，以上 4 つの物性值を基に構造形態推定を行つた。 図 6 に示すように, 三次元地震探査処理結果から, マルチ アトリビュート解析によって複数の物性值が算出されてお り, どの物性值を使用するかは坑井地質などの知見から選 定している。

構造形態推定においては, まず選定した物性值を三次元 物性モデルから坑跡近傍のデータを抽出し, 疑似検層デー 夕を作成した。その上で, ターゲットとなる層準ごとに疑 似検層デー夕からヒストグラムを作成し, 最適なしきい值 を選定した。図 7 に示すように, 速度は第 1 層区間が 2,019 $\mathrm{m} / \mathrm{sec} \sim 2,130 \mathrm{~m} / \mathrm{sec}$ (しきい值幅 $111 \mathrm{~m} / \mathrm{sec}$ ), 第 2 層区 間が 2,037 m/sec〜2,133 m/sec（しきい值幅 $96 \mathrm{~m} / \mathrm{sec）,}$ 第 3 層区間が $2,074 \mathrm{~m} / \mathrm{sec} \sim 2,154 \mathrm{msec}$ (しきい值幅 80 $\mathrm{m} / \mathrm{sec}$ ） と第 1 層区間のしきい值幅は広く, 第 2,3 層区 間では若干しきい值幅が狭くなっている。同様に, 震探 振幅值は第 1 層区間が-3.18〜2.04（しきい值幅 5.22), 第 2 層区間が-3.87〜3.89（しきい值幅 7.76 ), 第 3 層区 間がー4.17〜 2.38 (しきい值幅 6.55) と各層区間はゼロを 挟んで正負の值がしきい値となつたことから広い範囲で抽 出され，セルの絞り込み（基本手順の [6]）の寄与は低い ことが判明している。相対密度は第 1 層区間が -0.127 0.209 (しきい值幅 0.336 ), 第 2 層区間が $0.028 〜 0.275$ (し きい值幅 0.247 ), 第 3 層区間が $0.09 \sim 0.336$ （しきい值幅
0.246）であるが，ヒストグラムの最頻值を比較すると第 3 層区間の相対密度が大きく, セルの絞り込みの寄与は高く, 構造形態推定に貢献している。相対磁化率は第 1 層区間 が $-0.945 \times 10^{-3} \sim 1.586 \times 10^{-3}$ (しきい值幅 $2.531 \times$ $10^{-3}$ )，第 2 層区間が- $0.958 \times 10^{-3} \sim 1.41 \times 10^{-3}$ (しき い值幅 $2.368 \times 10^{-3}$ ), 第 3 層区間がー $0.996 \times 10^{-3} \sim 1.307$ $\times 10^{-3}$ (しきい值幅 $2.303 \times 10^{-3}$ ) と各層区間は震探振 幅と同様にゼロを挟んで正負の值がしきい值となったこと から広い範囲で抽出され, セルの絞り込みの寄与は低かつ た。

図 7 に示した 4 物性值のしきい值を満たすセルを, 坑井 マーカーから内挿によりガイドライン面を作成し, 制約条 件を与えて抽出した。抽出されたセルは層準の厚さとなっ ていることから, 最上面のセルで層準の構造図を作成した。 図 8 に示すように, 既往震探解釈図と比較して, 抽出され た構造形態の頂部と伸びの方向においておおむね整合性が あり，第 1 層上面の構造頂部が 3 層では北東側に移動して いることが既往震探解釈図とも整合している。しかしなが ら，既往震探解釈図では断層など短波長の構造変化を捉え ているのに対して, 推定された構造図では短波長成分はな く, 中波長以上の大局的な構造変化を捉えている。要因と しては, 地震探査データの方が深度方向の分解能が高いた め短波長の構造変化を解釈することが可能であったと考え ている。

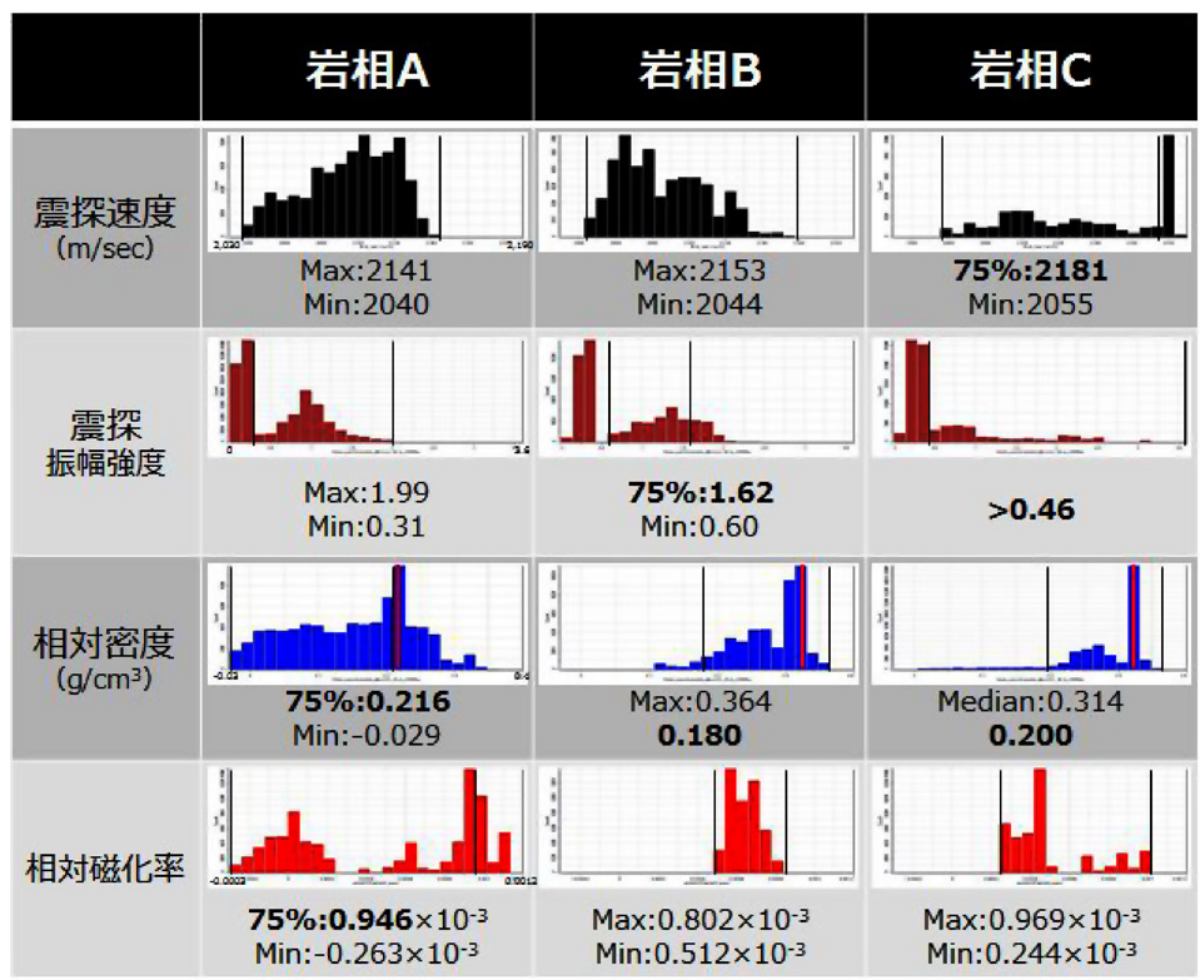

図 11 岩相推定で使用したデータのヒストグラムと最適なしきい值 選定した 4 物性における岩相ごとのヒストグラムと最適なしきい值（Max, Min）を示す。 


\section{4 岩相推定結果}

岩相推定手順については，三次元物性モデルから坑跡に 沿つて各物性値を取り出し疑似検層デー夕を作成し，夕ー ゲットとする岩相区間内の物性值のヒストグラムを作成す る。ヒストグラムから使用する物性値と最適なしきい値を 選定後，三次元物性モデルから全物性值のしきい值に収ま るセルを抽出し，岩相モデルを作成した。岩相推定を行つ たワークフローを図 9 に示す。

使用したデータは, 三次元地震探査処理結果のアトリ ビュートの一種である振幅強度と速度值, 相対密度と相対 磁化率の 4 つの物性值である（図 10）。

手順としては構造解釈と同様であるが, 三次元物性モデ ルから坑跡近傍のデー夕を抽出し, 疑似検層デー夕を作成 する。ターゲットとなる岩相ごとに疑似検層データからヒ
ストグラムを作成し，最適なしきい值を選定した。図 11 に示すように，速度は岩相 A が 2,040 m/sec 〜 2,141 m/ $\sec$ (しきい值幅 $101 \mathrm{~m} / \mathrm{sec}$ ), 岩相 B が 2,044 m/sec 〜 2,153 $\mathrm{m} / \mathrm{sec}$ (しきい值幅 $109 \mathrm{~m} / \mathrm{sec}$ ), 岩相 C が 2,055 m/sec 〜 2,181 msec（しきい值幅 $126 \mathrm{~m} / \mathrm{sec}$ ）をしきい值とし，岩 相 C においては最大值を累積分布関数 $F(0.75)$ に当たる 速度を採用し，セルの絞り达みの寄与を均等にした。既存 スタディで, 岩相 C の分布域と震探の強振幅域との相関 が指摘されていたことから震探アトリビュートの中から振 幅強度を採用して, 岩相 Aが $0.31 \sim 1.99$ (しきい值幅 1.68 ), 岩相 B が 0.6 〜 1.62 (しきい值幅 1.02 , 最大值を累積分布 関数 $F$ (0.75) に当たる相対密度), 岩相 Cが 0.46 より大 きい值をしきい值とした。しかしながら, セルの絞り込み の寄与は低く，振幅強度のみではなく連続性など総合的に

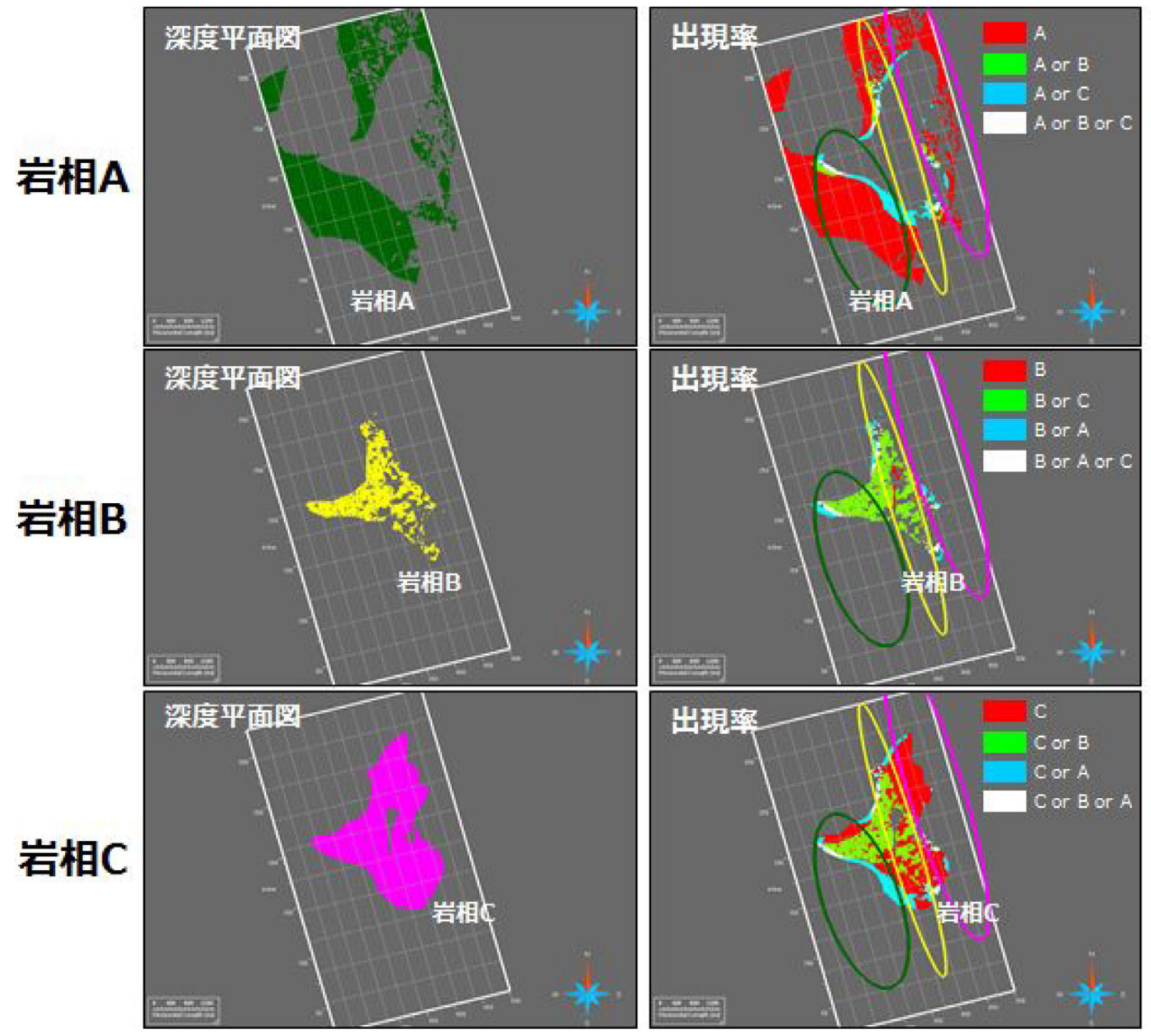

図 12 岩相分布推定結果と出現率

岩相ごとによる特定の深度における推定分布域の平面図と，同深度における出現率を示す。赤は単一岩相と推定された地域，緑と青 は 2 岩相が推定された地域，白は 3 岩相が推定された地域を示す。 
解釈担当者が相関を指摘していたと推測される。相対密 度は岩相 A がー0.029〜0.216（しきい值幅 0.187），岩相 B が $0.18 \sim 0.364$ （しきい值幅 0.184 ), 岩相 C が $0.2 \sim 0.314$ （しきい值幅 0.114）であるが, ヒストグラムの最頻值を比 較すると岩相 B と C の相対密度が同等であることから重 複することが予想される。相対磁化率は岩相 Aがー0.263 $\times 10^{-3} \sim 0.946 \times 10^{-3}$ (しきい值幅 $1.209 \times 10^{-3}$ ), 岩 相 $\mathrm{B}$ が $0.512 \times 10^{-3} \sim 0.802 \times 10^{-3}$ (しきい值幅 $0.29 \times$ $10^{-3}$ ), 岩相 Cが $0.244 \times 10^{-3} \sim 0.969 \times 10^{-3}$ (しきい值 幅 $0.725 \times 10^{-3}$ ) と岩相 B のしきい值幅が狭く, セルの 絞り込みの寄与は高かった。

図 11 に示した 4 つの物性值のしきい値を満たすセルを 抽出し, 深度平面図として岩相 A, B, C の分布域を表し
た（図 12 左）。岩相 $\mathrm{A}$ は, 南西域に広く広がり坑井地質 から予想される広がりと調和的であった。岩相 B は, 北 北西一南南東トレンドは再現できているが西方に延びるト レンドが認識できる。また, 岩相 $\mathrm{C}$ は, 坑井地質から最 も東側に分布すると予想されており, おおむね調和的で あった。

また，当該岩相に相当するセルを抽出する際には，岩相 毎に重複して抽出されたセルを記録しておき，重複してい るセルがどの岩相と重複しているかを出現率として深度平 面図に表した（図 12 右）。岩相 A は南西域と北東域で単 一岩相（赤）として抽出されており, 中央部付近では岩相 B (緑), C (青) との重複や未抽出域となつた。岩相 B は 中央部の限られた地域で単一岩相（赤）と抽出されたが,

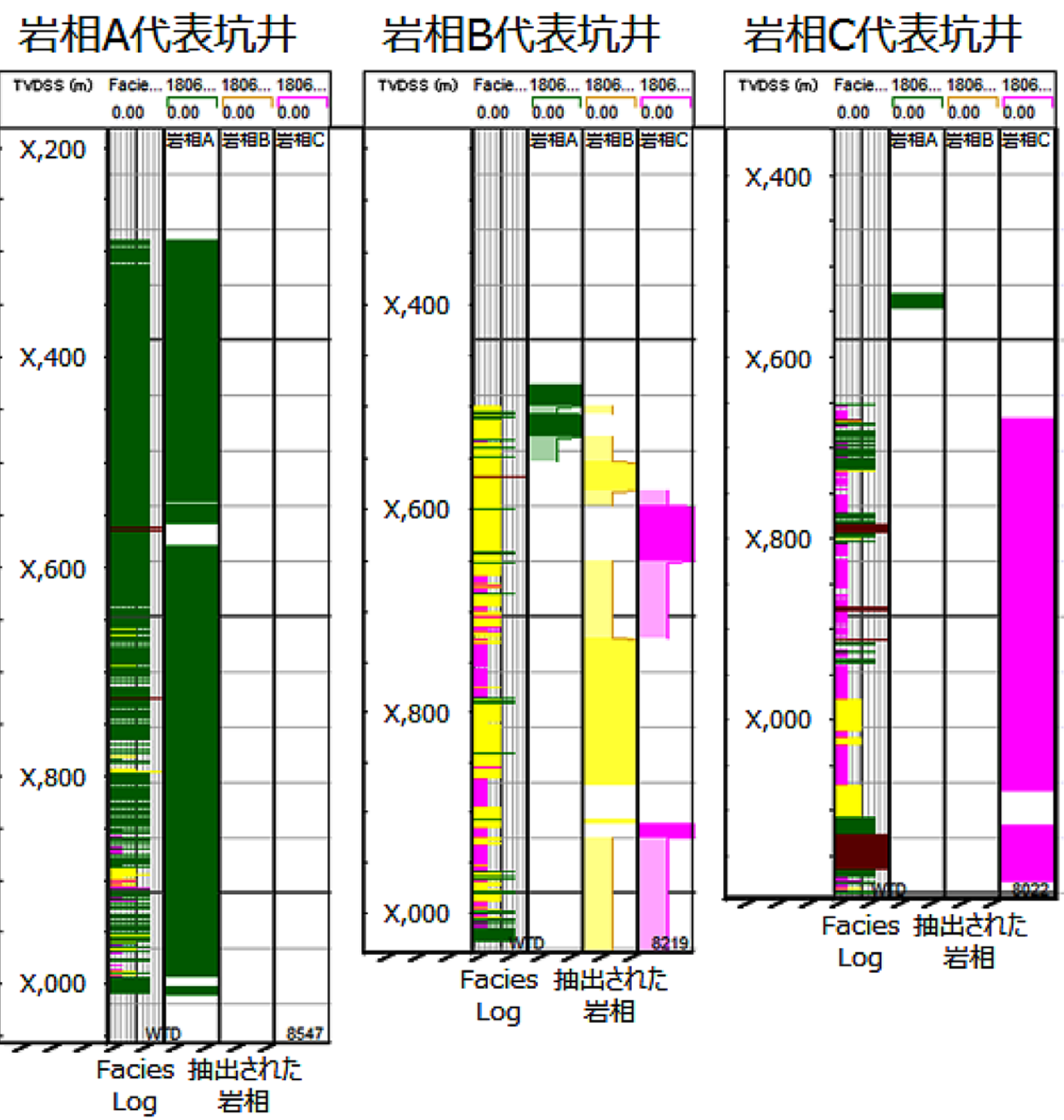

図 13 Facies Log と岩相抽出結果の対比

左列から検層データおよび FMI 解析から認定された岩相, 岩相 A の抽出結果 (緑), 岩相 B の抽出結果 (黄), 岩相 C の抽出結果 (ピンク) を示し，帯の幅は出現率（0～100\%）を表す。 
他の地域では岩相 C（緑）との重複域となった。岩相 B と Cのしきい值が類似しているため重複域が広がったと 考えている。岩相 C は中央より東側と南側で単一岩相 (赤) と抽出されたが, その他の地域では岩相 B (緑) との重複 域となった。

岩相モデルから坑跡に沿つて作成された疑似検層と検層 データから区分された岩相と比較を行った。図 13 に示す ように，岩相 A 代表坑井において，抽出された岩相は全 区間で岩相 A と認定され非常に良い岩相推定結果となつ た。岩相 B 代表坑井においても，抽出された岩相は B が 卓越しており良い岩相推定結果となっている。また，岩相 区分 C と混在する区間（X,900 m 以深など）では，抽出さ れた岩相 B とCの出現率が $50 \%$ として良く表現されてい る。岩相 C 代表坑井においても，抽出された岩相は全区 間で岩相 C と認定され非常に良い岩相推定結果となった。 3 坑井において, 比較対象とした岩相区分は，検層デー 夕およびFMI を解析することによって認定されており, Non-Seismic データの分解能を考慮すると十分に良い抽出 結果となったと考えている。

\section{4. まとめと今後の展望}

実証スタディを通じて，地震探査データに加えて異なる 物性值について高精度に測定する Non-Seismic データを複 数入力として統合解析・評価を実施することで，層準上面 および岩相の抽出ワークフローを構築することができた。 また，層準上面については，既往地震探査デー夕解釈との 整合性は良いことが判明し，岩相の抽出については，坑井 の岩相区分との整合性は非常に良かつた。

本実証スタディの目的であった, 解析手法標準化の試み は基本手順の作成によって達成されたと考えるが，ワーク フローで使用する物性值，ヒストグラム，しきい值などの 組み合わせを見出す上で試行錯誤が必要であり，適用する フィールドの地質学的特徵および坑井情報を十分に理解 し，パラメー夕選定および評価指針はフィールドの地質学 的特徵の再現度合いを比較検討しながら定めていく必要が あった。

地震探査データと対比して, Non-Seismic データは長波 長の物性不均質を捉えるため, Non-Seismic デー夕を含め た総合解析評価において，分解能のうち波長の違いが顕在
化しがちである。しかしながら, 火成岩などの岩相変化へ の適応の観点からは Non-Seismic デー夕は地震探査デー夕 に対して優位性を持ち, 本解析・評価結果において広域的 岩相推定には大きく寄与していると考えられる。

今後の課題としては, 今回の実証スタディでは, 各探査 デー夕単独の三次元インバージョンを実施しており, 物性 および岩相への感度が異なることからインバージョン結果 が整合しない場所があった。したがつて，各物理探査デー 夕の特徵を踏まえた統合されたインバージョンの実施は不 可欠であり, 解析手法の標準化において, ジョイント・イ ンバージョンを組み込むことは重要な課題であると考えて いる。さらに，ワークフローで使用する物性值の選定，し きい值の最適化において任意性が大きく, パラメー夕選定 の客観性を担保するために $\mathrm{AI}$ 技術を活用した物性值の選 定, しきい值の最適化についても課題として, 今後の解析 技術の進展に期待したい。

\section{謝 辞}

本稿の外部発表を許可して頂きました石油資源開発株式 会社に深甚の謝意を表します。

\section{引用 文 献}

Colombo, D., T. Keho and G. McNeice, 2012 : Integrated seismicelectromagnetic workflow for sub-basalt exploration in northwest Saudi Arabia. The Leading Edge, 31, 42-52.

Chakraborty, S., Choo, M. and Pedersen, H.T., 2013 : Looking Through the Haze - How CSEM can Improve Reservoir Imaging Where Seismic Struggles - A Case Study from Malaysia, 75th EAGE Conference \& Exhibition.

地質調査総合センター, 2005 ：日本空中磁気データベース. 数値地質図 P-6，地質調査総合センター

Mark Dransfield, 2010 : Conforming Falcon gravity and the global gravity anomaly. EAGE Geophysical Prospecting, 58, 469-483

Stein F., Pål T. G. and Svein E., 2014 : CSEM as a tool for better exploration decisions: Case studies from the Barents Sea, Norwegian Continental Shelf, SEG Volume 2, Issue 3, SH55-SH66. 